\title{
Civilisations
}

Revue internationale d'anthropologie et de sciences

humaines

$61-2 \mid 2013$

Chamanismes en mouvement

\section{Sick of Shamanizing}

In Search of Healing on the Kamchatkan Roads of World-Jesus

\section{Patrick Plattet}

\section{(2) OpenEdition}

1 Journals

\section{Electronic version}

URL: http://journals.openedition.org/civilisations/3217

DOI: 10.4000/civilisations.3217

ISSN: 2032-0442

\section{Publisher}

Institut de sociologie de l'Université Libre de Bruxelles

\section{Printed version}

Date of publication: 28 June 2013

Number of pages: $69-88$

ISSN: 0009-8140

\section{Electronic reference}

Patrick Plattet, «Sick of Shamanizing », Civilisations [Online], 61-2 | 2013, Online since 30 June 2016, connection on 30 April 2019. URL : http://journals.openedition.org/civilisations/3217 ; DOI : 10.4000/ civilisations. 3217

\section{(c) Tous droits réservés}




\title{
Sick of Shamanizing \\ In Search of Healing on the Kamchatkan Roads of World-Jesus
}

\author{
Patrick PLATTET
}

\begin{abstract}
In the Russian Federation, religiously motivated mobility phenomena have grown rapidly in the post-Soviet aftermath. In Kamchatka (Russian Far East), the main driving force behind religious mobility is a neo-Pentecostal missionary movement that spread from Ukraine in the late 1980s. Native forms of "shamanizing" are not absent from this new Christian world. Some of their emblematic features, such as drumming, travelled all the way from Northern Kamchatka to the urban churches of the movement where they became charismatic. By contrast, the making of zoomorphic "idols" conveys the idea of a sickness that requires appropriate religious healing. In this paper, I examine how drumming and idol worshipping are respectively carried away and left behind on the new roads of faith opened in post-Soviet Kamchatka. I look at how shamanizing can be at the same time a remedy against post-Soviet harms, and a pathology from another time. I suggest that this twisted view blurs the (already blurry) definition of shamanism in Kamchatka and keeps a handful of Pentecostals on the move.
\end{abstract}

Keywords: Shamanism, Pentecostalism, Mobility, Drumming, Rituals, Kamchatka.

Résumé : Dans la Fédération de Russie, les phénomènes de mobilité à motivation religieuse ont connu une croissance rapide dès les premières heures de la période postsoviétique. Au Kamtchatka (Extrême-Orient russe), le principal moteur de ces déplacements est un mouvement missionnaire d'inspiration pentecôtiste parti d'Ukraine à la fin des années 1980. Ces nouveaux circuits évangéliques ne sont pas dépourvus de formes indigènes de "chamanisation". Certains attributs phares, comme jouer du tambour, ont voyagé depuis les confins du Nord-Kamtchatka jusque dans les églises urbaines du mouvement et sont devenus charismatiques. À l'inverse, la fabrication "d'idoles" zoomorphes véhicule l'illustration d'une maladie grave dont il faut guérir. Dans cet article, je me penche sur les modalités d'incorporation et de mise à distance du jeu de tambour et de la vénération d'idoles sur les nouvelles routes de la foi ouvertes au Kamtchatka postsoviétique. J'examine la façon dont chamaniser constitue à la fois un remède aux maux contemporains et une pathologie d'un autre temps. Je suggère que cette perspective alambiquée brouille la définition, déjà floue, du chamanisme au Kamtchatka et permet à une poignée de pentecôtistes de prendre la route.

Mots-clés : Chamanisme, pentecôtisme, mobilité, jeu de tambour, rituels, Kamtchatka. 


\section{Introduction}

Since its discovery by Russian explorers and Cossacks in the late $17^{\text {th }}$ century, the Kamchatka Peninsula in the Russian Far East has often been portrayed as a land on the margin. For more than three centuries, Kamchatka's geographical and spiritual remoteness has given rise to large-scale evangelical movements and scientific expeditions. Surely, if this dreamland was as far removed as predicted, it could only be home to all kinds of exotic yet-to-be-reached people: pagans, idol worshippers, shamans, and the like. To verify (and sanction) these expectations, the Russian Orthodox Church led the Christianization of Kamchatka in several stages between 1697 and 1919 (Belashov 2000). From "Peter and Paul" (Petropavlovsk), the city founded in southeastern Kamchatka by Vitus Bering in 1740, a succession of military-religious expeditions progressed north along the Western shore of the Peninsula to open new roads of trade and new itineraries of faith. As anticipated, idolatrous "pagans" (iazychniki) were found everywhere (Ibid.: 113-231) and were evangelized - with varying success - in a context of displacement and disease brought about by colonization. A clear distinction of "shamans" (shamany) among the pagans was more difficult to establish, even by prominent scientists. A member of Vitus Bering's Second Kamchatka Expedition (1733-1743), German naturalist Georg Wilhelm Steller noted that in $18^{\text {th }}$ century Kamchatka "whoever wants to shamanizes" (Steller 2003:209). Were all pagans endowed with shamanic skills (without necessarily knowing it)? Were shamans (intentionally) hiding under the guise of shamanizing pagans, possibly to avoid further persecution? This ambiguity remained unresolved a century and a half later during the Jesup North Pacific Expedition (1897-1902). A member of this expedition, Russian ethnographer Waldemar Jochelson coined the term "family shamanism" to compensate for the near absence of professional shamans in Kamchatka (Jochelson 1908: 54-64). What Jochelson meant by family shamanism were common ritual practices seen in many native Koryak households, such as playing the drum and uttering incantations ("shamanizing" in Steller's words). Thus, by a conceptual sleight of hand, average ritual efficacy had something to do with shamanism. And drummers were somehow related to shamans. Exactly what and how was unclear. In this paper, I seek to show that ethnographic evidence of this uncertainty still exists. I contend that blurring the lines between pagans, idol worshippers and shamans does not so much constitute an obstacle to Christian missionary movements in contemporary Kamchatka, as it contributes to fueling them.

The Christian evangelization of Kamchatka was slowed down drastically during the Soviet era, especially when the region was declared a closed military zone during the Cold War. It has, however, gained new momentum as soon as the USSR began to crumble. Once again, missionary activities expanded in a context of social and sanitary “disaster" (King 2003:391). Rural communities were particularly affected as everybody abandoned them, including the Russian Orthodox Church. The evangelical cure for Kamchatka's marginalization was now carried out by a neo-Pentecostal Protestant 
movement known as "World-Jesus". ${ }^{1}$ Originally started in Ukraine as "Arctic-Jesus" (1987), World-Jesus (1995) reached the Russian Far East in the late 1980s and gave birth in 1999 to the "Union of the Kamchatkan Churches of Christians of the Full Gospel". As of 2011, this union - called "Good News" or KamUnion - had twenty-two churches scattered all around Kamchatka Peninsula and beyond (Commander Islands, Kuril Islands). ${ }^{2}$

Most of these churches use old Soviet buildings as places of worship. A nexus of this network is a Missionary Centre and Bible College located in a forest not far from Kamchatka's capital Petropavlovsk-Kamchatskii. A former Soviet pioneer camp, this "Base" (Baza) now serves as a hospice where people suffering from various forms of what is called idolopoklonstvo ("idolatry") come to be healed. For those in KamUnion, idolatrous practices include "paganism" (iazychestvo), "alcoholism", and even "hooliganism" (khuliganstvo). Combining evangelization and community assistance is not an entirely new initiative in the region. Already in 1910 bishop Nestor of Kamchatka established a charitable brotherhood for the Kamchatka Orthodox mission and travelled far and wide across the Peninsula to provide help and education to those in need (Belashov 2000:239-245). The novelty is that the 'sufferers', rather than being simply missionized in their home villages, are now encouraged to travel to KamUnion's Base. A few interns are native men and women who have journeyed all the way from Northern Kamchatka after their repentance and acceptance of Jesus Christ as their Savior at home. For those from rural areas, the only way to "heal all aspects of the born-again convert's life" (Gooren 2010:95) is to follow the standard recovery procedure within KamUnion. This consists of a maximum of two years' residency at the Base, and involves periods of theological training at the Bible College (3-6 months) and internships in affiliated village congregations (2-3 months).

1. The first Pentecostal communities in the Russian Empire appeared in the early 1910s. In the USSR, they were persecuted (especially during the Great Terror of the late 1930s) and declared illegal in 1961. A new type of Pentecostalism emerged in the late 1980s/early1990s when foreign Pentecostal churches, unions, and missionary movements began to proselytize in the former Soviet Union introducing new manners of worship and ideas (including emotional praise, rock music, mass healing, and other signs of spiritual gifts). In the Russian scholarly literature, Pentecostal churches that did not accept these innovations are known as "traditional" or "conservative". By contrast, Pentecostal churches established in the 1990s that adopted new forms of worship (such as those discussed in this paper) are often labeled as "Charismatic" or "neo-Pentecostal" (Lunkin 2004, 2005).

2. Following the Russian Law on Freedom of Conscience and Religious Associations passed in 1997, no religious congregation can secure legal status unless it has existed for fifteen years or belongs to a centralized religious organization (Lunkin 2005). KamUnion is affiliated with "The Russian Church of Christians of Evangelical Faith", one of the two major Evangelical-Pentecostal associations in Russia. Although KamUnion is now registered as a union of churches, many of its local congregations are still in the process of seeking registration with the government as affiliated churches of KamUnion. 


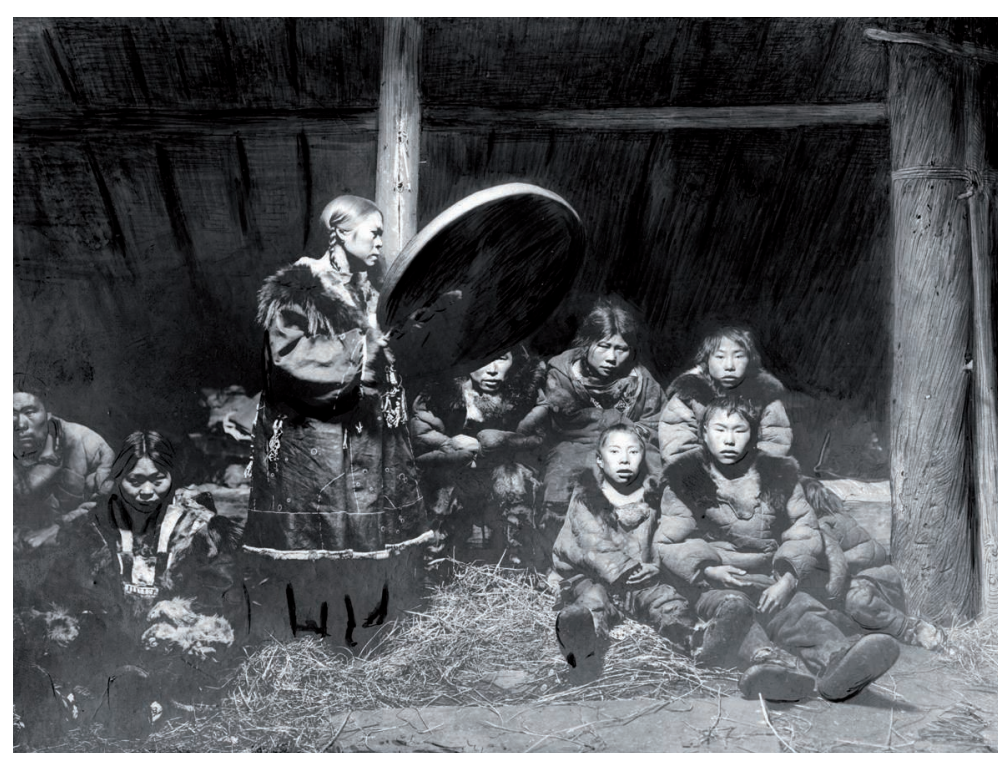

Photo 1: "Shamanistic performance".

Courtesy of the Division of Anthropology Archives, American Museum of Natural History (Plate 3, Jochelson's The Koryak, Memoirs of the AMNH Vol. 6, Pt. 1).

Within World-Jesus, "the North" (Sever) is the semi-fantasized universe where pagan misbeliefs are said to have survived until contemporary times. After graduation from the Bible College, native Brothers and Sisters are often "asked by God" to go back to the North. In this paper, I retrace the main steps of their round trip across KamUnion. I start from the time in the late-1990s when they felt ill and forgotten at the end of the world and follow one of them until her full transformation as mobile pastor in the early 2010s. ${ }^{3}$ This involves distinguishing between the few Brothers and Sisters who are given the opportunity to travel, and the majority of them who are trapped at the margins of World-Jesus as a result of their failure to break with the past, a theme heard in other Pentecostal missions around the world (see, e.g., Meyer 1998). Throughout the Russian North, interacting with "idols" (idoly) made of natural material (wood, bone, hide, etc.) has long been seen by all kinds of Christian missionaries as the most salient symptom of an incapacity to discontinue the shamanic tradition (see Plattet 2011; Vallikivi 2003; Vaté 2009:46). Within KamUnion, however, other 'archaic' modes of ritual action that were supposed to be left behind turned out to be "portable practice" (Csordas 2009:4). Playing the drum became increasingly charismatic over the last decade. Unlike shamans (whose uncertain presence has been reduced even more by the

3. Ethnographic data for this article were produced during ongoing fieldwork in Kamchatka since 1999. Research on new religious movements in Kamchatka was supported by a grant from the Swiss National Science Foundation (\#PA001-113073) awarded in conjunction to the collaborative research project NEWREL (New Religious Movements in the Russian North) of the European Science Foundation EUROCORES programme BOREAS, and by a Regional Center Grant from the University of Southern California and the John Templeton Foundation awarded in conjunction to the Pentecostal and Charismatic Research Initiative. 
Soviet anti-religious repression), drums were still alive in 1990s Kamchatka (see King 2011). They could be converted from an emblematic tool of family shamanism and Koryakness into a potent releaser of God's power. Thus, through what Meyer calls "a dialectics of appropriation and rejection of "the past"" (1998: 332), drumming became part of the antidote to shamanizing and is now a driving force of the circulation of Good News theology across Kamchatkan cultural borders. In this article, my questions are: How can we make sense of the mutual muddling of the categories of pagans, shamans, and idol worshippers within World-Jesus? How far did drumming have to go in order to be used as a remedy against shamanizing? Does "Pentecostal mobility" (Droogers et al. 2010) provide full protection against ancestral pathologies? I argue that one answer to these questions is to be found in the never-ending reenactment of old rituals, seen as "dirty" (griaznye) and "boring" (skuchnye) all over KamUnion. I suggest that such views allow for a representation of those who take part in these rituals as being sick with idolatry and sick of shamanizing.

\section{Shamanizing as pathology: The travel of an idea}

Scholarly representations of shamanism started to treat shamanic behavior as pathological already in the early $19^{\text {th }}$ century (see Hamayon 1998: 179-180). Later, at the turn of the century, manifestations of "spiritual nonconformity" within the Russian Orthodox Church were similarly pathologized (see Beer 2004: 452). In the 1960s and 1970s, it was the turn of historic or traditional Pentecostals in the Soviet Union to be accused and persecuted on the ground of "savage ritual" (Panchenko, forthcoming). More recently, the idea that some ritual acts are dirty and harmful was expressed to me by Maria, the Koryak pastor of the "Church of Jesus" in the native village of Berezova. ${ }^{4}$ Besides a church of KamUnion, this small coastal settlement of northwestern Kamchatka also had a "hospital" (bol'nitsa) at the time of my last visit in 2006-2007. This meant that the community was deemed viable by Kamchatka's authorities and was not facing immediate closure. ${ }^{5}$ However, signs of weakness were apparent. The dispensary was only offering rudimentary healthcare during the day. At night it was turned into a dormitory where rare visitors like my wife and I could stay for free in a patient's room. I first met Maria in the waiting room of the hospital. ${ }^{6}$ Maria had been a member of "the church" (tserkov') since 1998, the year when three missionaries of World-Jesus first reached Berezova. In her early thirties at the time, she was teaching mathematics at Berezova's secondary school. Her hobby was poetry. As of 2011, Maria was the only woman pastor who had been ordained by the Ukrainian-born Bishop of KamUnion. According to her, the cold from which she had suffered prior to my arrival in October of 2006 was nothing compared to her condition in the late 1990s. During

4. Pseudonyms are used to protect the privacy of individuals, places, and religious institutions whenever their identity is not broadly shared public knowledge.

5. In 2007, the population of Berezova was approximately 500, out of which $95 \%$ were Koryak. Not yet registered, the Church of Jesus was composed of about thirty adult Koryak members.

6. I had two (unrecorded) conversations with Maria in October of 2006 just before she left Berezova to complete her training at the Base. I tried to meet again with Maria in 2011 when I carried out interviews with pastors and lay members of KamUnion, but I was unable to reconnect with her as she was serving as pastor on the Bering Island. 
our second meeting, she told me how close she was to committing suicide before the advent of the missionaries. Indicating the parts of her body between the neck and the lower abdomen, she remembered the time when she felt sick from the inside and alone on the shores of the Sea of Okhotsk.

In Maria's view, the most likely cause for the profound bodily disorder and the deep social marginalization that she experienced in the 1990s was the persistent curse of ancient shamans. This idea echoed stories circulated within KamUnion (and beyond) by the founding leaders of World-Jesus since the early 1990s. In a recent interview that she gave to an online "megaportal of Christian resources" in Russian, Larissa, a leading official of World-Jesus, emphasized ubiquitous shamans as the main source of missionary attraction in Kamchatka:

We didn't fly just once to the Russian Far East. We went several times to remote places, to villages, to prisoners' settlements, we went through many homes and we preached the Word of God, distributing Christian literature. We preached to SHAMANS [original emphasis]. We were very happy when people received Christ in their hearts and lives. We were also very happy when a whole family of shamans repented. (Invictory.org 2010)

In places like Berezova, however, families of shamans were nowhere to be found. To accommodate the mythology of World-Jesus, Maria was formulating a connection between "shamans" and "idol worshippers" - their closest kin in her view. In her discourse, the former (shamany) belonged to the time of the "ancestors" (predki) (cf. Meyer 1998:323, 326). They were aware of their knowledge and used it intentionally "to contaminate" (zagriazniat') people. Even though shamans do not exist anymore, their afflictive intentions survived them. The contaminating power of dead shamans spread all the more easily over time because their descendants "already don't know" (uzhe ne znaiut) how to handle it. Following this loss of knowledge, inhabitants of Berezova were reduced to the state of "idol worshippers" (idolopoklonniki). According to Maria, idol worshippers were not shamans. Yet, by fabricating and pleasing idols they relentlessly continued "to shamanize" (shamanit') without a clear awareness of the danger inherent to their practices. They were "SHAMANS" in the sense of surreal prisoners of unseen forces and agencies that drive the cyclical movement of "dirt" ( $g r i a z ')$ across ages. Thus for Maria the timeless reiteration of unhealthy ritual practices was not only perpetuating old diseases, it was the disease.

In present-day Berezova, "idols" refer primarily to wooden effigies of big-game animals hunted on the local territory (mountain sheep, grizzly bear, and harbor/bearded seal). These small zoomorphic representations are built once a year, in the fall, during a collective ritual called Ololo (see King 2011:89-93; Plattet 2011; Urkachan 2002; Vdovin 1973). In Ololo, the material for crafting wooden bears, seals and sheep is taken from a "tree of luck" (kor. likron 'mrai). ${ }^{7}$ In the frame of the ritual, this alder tree is the special guest that local families must manipulate and entertain during an entire night of drumming, dancing, and singing. Maria believes that her family paid a heavy toll for such idol worshipping. All her relatives on her father's side died from stomach

7. Indigenous terminology is given in Russian except when Koryak language applies. In this case, the sign "kor." for "koryak" precedes the native term given in parentheses. 
cancer, while all her relatives on her mother's side died of liver cancer. In her eyes, this hecatomb was caused by an overdose of Ololos.

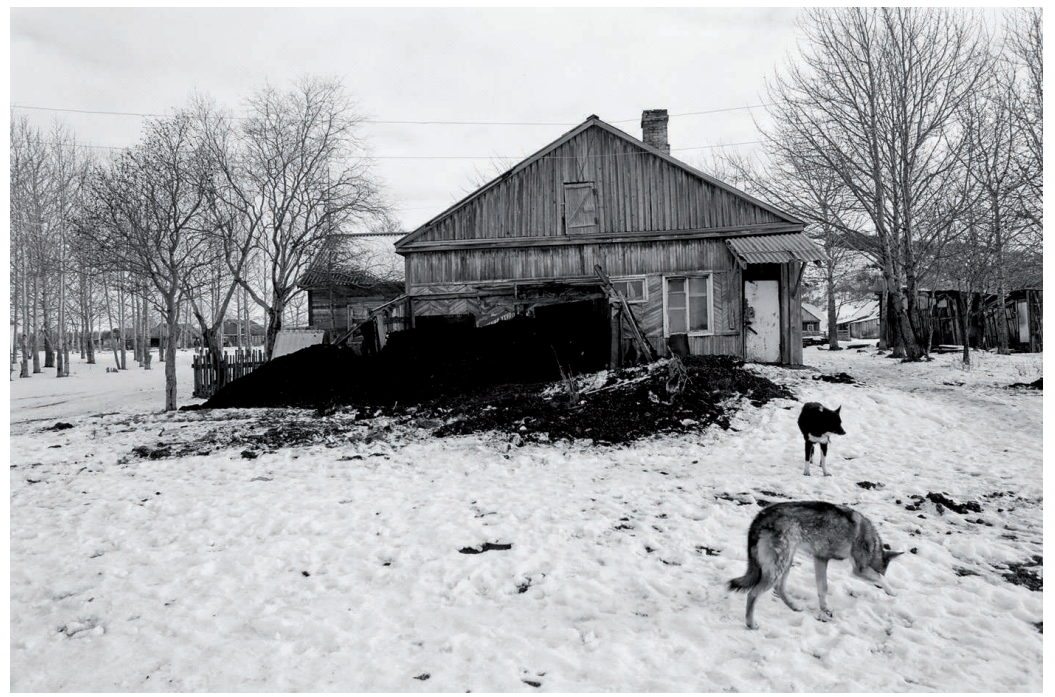

Photo 2: Pile of heating coal behind Berezova's hospital. (C) Maïté Agopian, December 2006.

In order to understand Maria's pathological view of shamanizing acts, it is necessary to examine it in relation to a broader "context of conversion" in the Russian Far East (Vaté 2009: 40-43). Berezova was progressively reached by and converted to Christianity long before the rise of World-Jesus. On February 12, 1837, after more than a century of preliminary contacts established by itinerant priests who were so "uninformed" and "untrained" that even native Kamchatkans were "admitted to this dignified office" (De Lesseps 1970: 135-136), the Russian Orthodox Church in Kamchatka sanctified a chapel of St-Nicholas in Berezova (Gromov 2000: 155-160). This achievement was meant to implement the program of "transformation of the spiritual sphere" (preobrazovanie dukhovnoi chasti) in Kamchatka between 1823 and 1840 (Ibid.: 70-87). Diseases and the question of their origins were already a central issue in this transformative process. In his inaugural address to the inhabitants of Berezova, visiting archpriest Procopius Gromov explained that the "endemic disease" (poval'naia bolezn') that was ravaging Kamchatka did not follow the arrival of missionaries, but was "confirming superstitious hesitations" (Ibid.: 156). He justified the appointment of a Russian Orthodox priest in Berezova by arguing that his presence would save the community from its misfortune. Due to a succession of poor salmon runs, however, food was scarce in Berezova during the time of the parish mission (1837-1843). According to Gromov (Ibid.:90), the priest had a hard time carrying out his duties. Despite all his efforts, he could neither overcome the lack of fish and bread, nor get used to fireweed root, seal meat or beluga fat. He gave up after six years of struggle. In 1843, the keys of Berezova's chapel were left in the hands of Koryak proselytes, a shift of ownership that would favor the shaping 
of an indigenized form of Orthodoxy, in which alder wood and drumming (among other things) came to occupy a central position. ${ }^{8}$

Many native (and non-native) Kamchatkans still considered themselves "Orthodox" (pravoslavnye) in the immediate post-Soviet aftermath (Koester et al. 2010). Moreover, when World-Jesus reached Berezova for the first time "around June 20 of 1998", the local population was facing yet another period of great deprivation. Due to massive shortages of coal in the Russian Far East, the village had just come out of one of the coldest and darkest winters in living memory. Grocery stores were empty (except with bootlegged vodka), and people were surviving on pine nuts, wild roots and dried salmon. The humanitarian crisis took a particularly tragic turn in 1999 when many elders died of cancer in Berezova. From the mid-1990s to the mid-2000s, high levels of death and distress were common in Kamchatka and had important repercussions on the mortality and birth rate of the indigenous population (Robert-Lamblin 2011:125). Those who survived or were born during this period of poor diet and low medical access were chronically exposed to tuberculosis, stomach disorders, STDs, etc. In this end-oftime atmosphere, incoming missionaries found what they were expecting: a society that was seemingly prisoner of its past, displaying alarming signs of marginalization and immobility, and therefore suffering from all kinds of moral and physical illnesses. On the other hand, many elders in Berezova saw the reappearance of the missionaries in 1998 as a return to the time before the Orthodox chapel was "killed" in 1940, and before God was confined to the private domain. This perception started to change when it became obvious that the new missionaries were not Orthodox. But what were they exactly? "Baptists" (Baptisty)? "Evangelists" (Evangelisty)? "Charisma-something" (Kharizma-chto-to)? The uncertain label of the new religion gave rise to tensions and divisions within the community. According to the new "believers" (veruiushchie), a school of fish came straight to the nets of those who accepted Jesus in their heart, while fishing remained desperately low for those who did not pray. The death of the elders and the health issues of the villagers were now subject to conflicting views. On one hand, the perspective of being reborn in Christ generated a critical discourse on native culture. While not totally toxic, the old way had nevertheless revealed its pathogenic nature: "Our fish is good but we eat it salted or dried and without vegetables, that's why we suffer from stomach aches." On the other hand, staying faithful to popular Orthodoxy meant viewing the new "Christians" (khristiane) as a "sect" (sekta) spreading like a madness in the post-Soviet mayhem: "They sing and jump all over the place, it's like going crazy".

In this atmosphere of dissension, local families were far from being united in their acceptance of, and conversion to an uncertain new faith. The rejection of ancestral ritual practices promoted a "culture against culture" (Dombrowski 2001). Yet at the same time, enmeshment with the (pre-)Soviet past made it challenging to keep up with the Pentecostal "production of discontinuity" (Robbins 2010:163) that can be "difficult to achieve" in indigenous communities where traditions "still matter" (Meyer 1998:340; see also Vaté 2009). For example, without an actual church building, followers of Jesus

8. Similar phenomena happened elsewhere in the circumpolar North and generated many dialogues between native religions and Christianity (see in particular Laugrand 2002 and Znamenski 1999, see also Vallikivi 2003, 2009). 
hold their main worship service in the old "House of Culture" (Dom Kul'tury) that they rent from the local administration. ${ }^{9}$ Decades of indigenization of Russian Orthodoxy and of resistance to Soviet acculturation seem to have sped up the protection against KamUnion's counterculture. In a matter of just a few years, by tolerance as much as by pragmatism (see Lambert 1999-2000), the Church of Jesus became full of drumming and dancing - arguably not unlike what may have happened in the chapel of St-Nicholas after 1843.

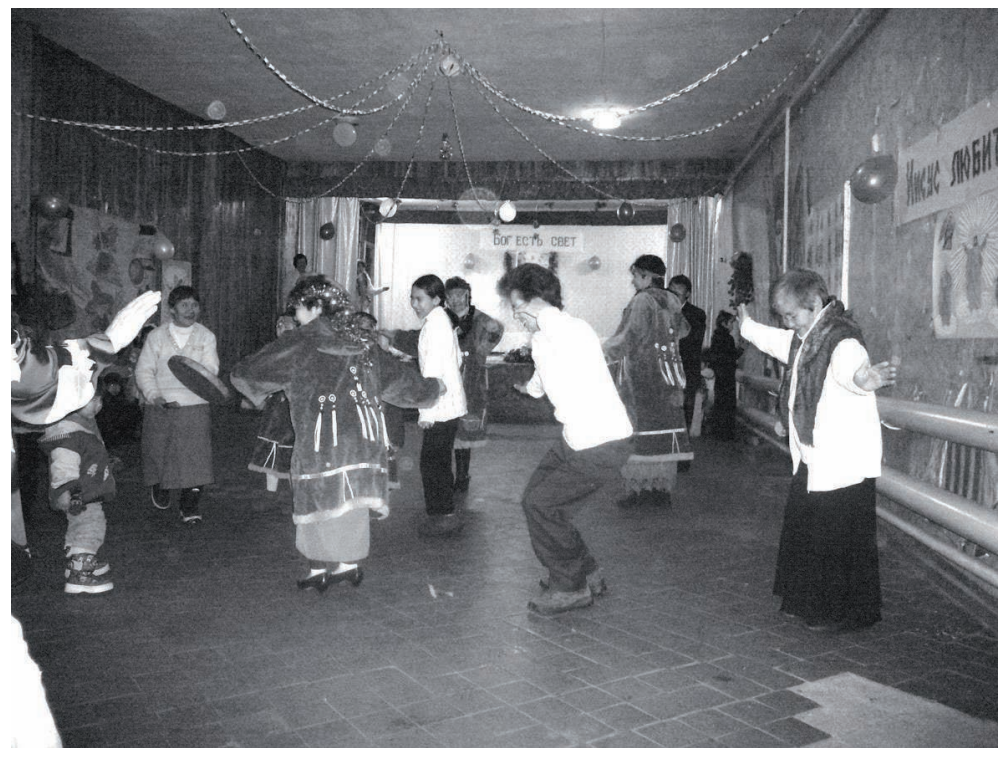

Photo 3: Drumming and dancing inside the House of Culture/God, Berezova. (c) Patrick Plattet, January 7, 2007.

\section{The movement of God: Pastors'views on mobility, idols, and drumming}

Maria was first introduced to me by Anna, a head mistress at the hospital whose job was to keep the place salubrious. The two women were not on the best terms in 2006. Anna and Maria were both in their late thirties and had known each other since their childhood. However, Anna had recently taken the decision to quit the church of which Maria was the pastor. Married to a hunter who was often gone sable trapping or seal hunting, Anna was raising three children on her own. She did not find enough time to meet the many social and religious demands of the congregation. Anna was also concerned about the compatibility between the Good News theology and a set of practices that she referred to by the Russian word shamanit' ("shamanize"). One question was particularly important to her. Was she allowed, yes or no, to play the drum, dance, sing, and help craft wooden effigies of big game animals during Ololo?

9. The designation and the day of this service (obshchee sobranie - "general meeting", hold on Saturday), also suggest partial overlapping rather than radical rupture with the Soviet past. For more information on the social significance of Houses of Culture in Russia and how they have changed in recent decades, see the volume edited by Donahoe and Habeck (2011). 
That question remained unanswered during her short life as a "Christian". Maria had recommended that Anna not attend the pagan celebration. Others, like Alexander, a former biathlon champion in his late thirties who led several missions of KamUnion to Berezova, were advocating to "let go" the past while keeping in touch with (healthy) traditions:

There is a lot of idol worshipping in our culture. When I talk about that to our people, especially to grandmothers, some agree, and some... It's difficult for them to agree because they worry a lot that they'll have to abandon all that they have learned in their childhood. So I have to explain to them how Christians can carry out traditional ways of life and remember their culture without going back to the past, to idol worshipping. (Alexander 2011)

Yet, many followers of Jesus did not want to miss the annual "feast of the animals" (prazdnik zverei). An arrangement emerged according to which attending Ololo was acceptable, while interacting with the tree of luck was prohibited. Anna had a hard time making sense of this rule. As a member of a prominent family of hunters, she was committed to helping rebuild wooden bodies for the seals, bears, and sheep that her husband and son killed during a year of hunting. Moreover, Anna's grandfather was remembered as someone who "knew" (znal). He was not exactly a shaman (except according to some in the church), but a great hunter with extraordinary skills such as being able to trap a bad wind in his tobacco case. This kind of knowledge was lost, but not the power of the knowledge, which somehow was still flowing in Anna's veins. Her addiction was considered so high by other Brothers and Sisters that Anna was put in the category of persons in high need of religious healing. After she quit the church, Anna felt that her former pastor and other church members were avoiding her, as if she were contagious. She was unhappy about this situation but did not know what to do about it. Leaving was not an option. Her renouncement of Jesus was also a renouncement of the hope of traveling far from her village. By contrast, I learned during my last incursion into World-Jesus in the summer of 2011 that Maria was "told by God" (Bog ei skazal) to serve on the Bering Island. For her, religious mobility was now part of the remedy against ancestral pathologies.

Leaving Berezova helped Maria realize how similar her recovery experience was to what other born-again pastors of KamUnion had gone through in the 1990s. In the provincial town of Apala, closely connected to Petropavlovsk-Kamchatskii, the "Church of the Testament of Life" is one of the three registered congregations of KamUnion. ${ }^{10}$ Here the church owns its House of Culture/God. As a result, the process of reworking and "recycling secular into religious" (Luehrmann 2005:40) went further than in Berezova. The movie theater room became the worship hall, the ballroom was split into a kitchenette and an office, two one-room apartments were created, and the main stage was transformed into a fireproof altar. Concerns about health were no less visible inside this renewed church's body than within the remote cell groups of Berezova. Boris, the charismatic and ultra-spirited pastor of Testament of Life, was often asking his Sister from the front office to monitor his blood pressure. As presbyter of KamUnion living

10. In 2011, the Church of the Testament of Life was composed of about eighty members, an overwhelming majority of which was non-indigenous. 


\section{Sick of Shamanizing}

on the Base, he was also answering prayer requests from those who had "problems in their organism".

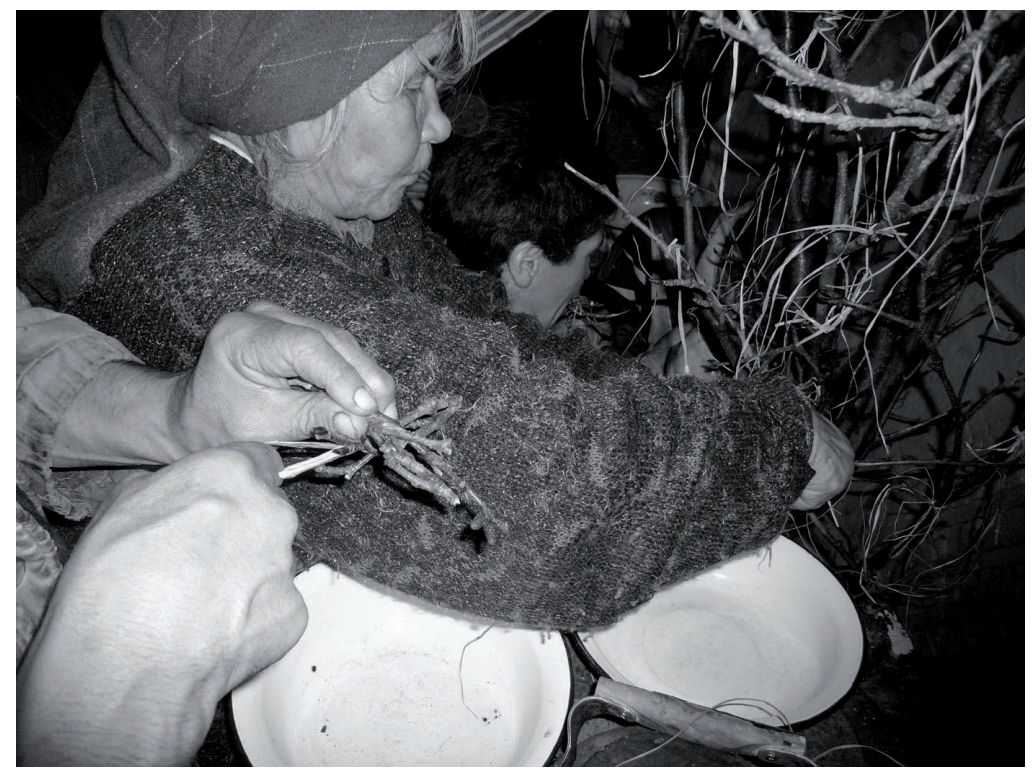

Photo 4: Crafting a wooden seal during Ololo.

(c) Patrick Plattet, October 30, 2006.

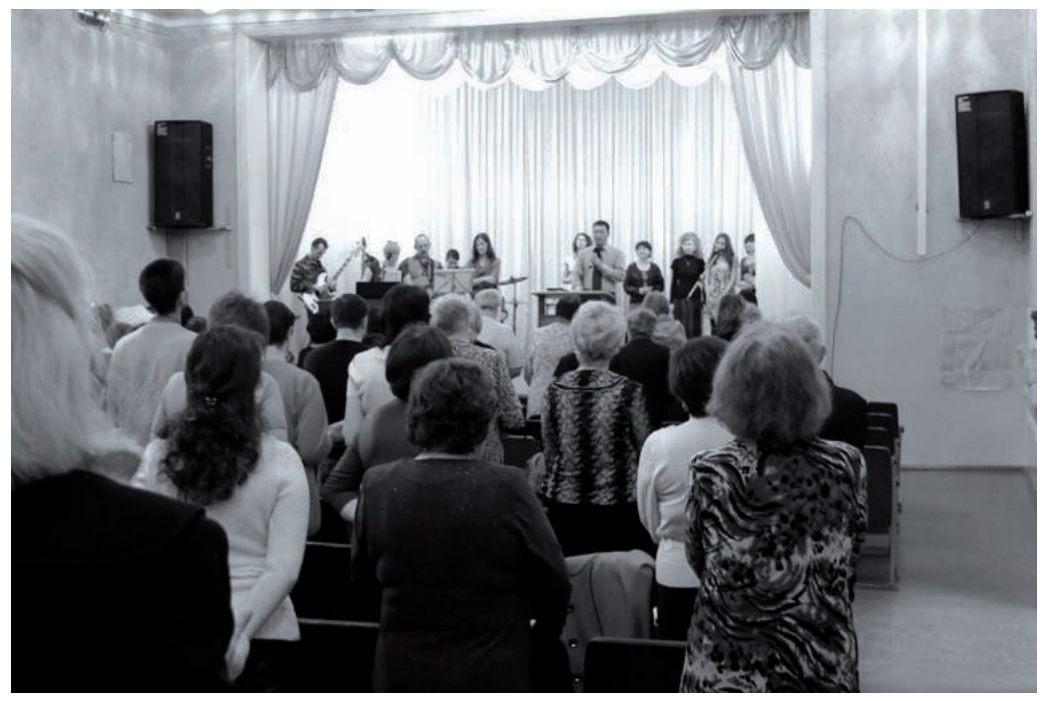

Photo 5: Sunday service in the Apala church.

(C) Patrick Plattet. 
Now in his forties, Boris once made the trip to Palana, the closest town from Berezova. His one-week service there forced him to believe that his Brothers and Sisters from the North "will survive anywhere". Yet Boris too was a survivor. Born of a Korean father and a Russian mother, he spent four years in a Kamchatkan jail for chronic violence in the early 1990s. He was sentenced after having been diagnosed with "hooliganism" (khuliganstvo), another kind of recognized social ill leading to isolation in the Russian Federation (cf. Cohen 2006). As in Maria's description of her imprisonment in Berezova, Boris's cell was dark and cold. And like his Sister Pastor from the North, he was saved when a missionary light warmed his life:

We made a large iron thing, like a pool, and we brought water overnight. We warmed it a little bit because it was very cold on September 1 [of 1992]. We had cold water [in prison]. And he came and baptized us in water. Yes, it was a great feast. (Boris 2011)

In Boris's case, "he" was one of the founding creators of World-Jesus for whom prisoners like Boris and shamans like Anna were attaching too much importance to the wrong gods in the forms of idols, therefore suffering from the same "sickness" (bolezn'):

What is an idol? Idol means 'trust'. For instance, I 'trust' this radiator heater and I worship it because I am convinced that my life depends on it. You understand? I let this radiator control my life [to the point that] it rules my life and that even the Lord cannot help me. That's what idol means. An idol can be anything in my life. Any household object or utensil in my life may be an idol if I attach too much importance to it. (Boris 2011)

Whether an idol takes the form of a radiator (in a jail of Southern Kamchatka) or of a wooden grizzly bear (in a hunting ritual of Northern Kamchatka) is not important. In the eyes of KamUnion, what matters is the campaign against all forms of idolatry as a cause of social marginalization and health decline. The crusade against idolatry, alcoholism, hooliganism, etc., is one and the same. Only the "movement of God" (dvizhenie Bozhe) can work as an efficient medicine and prevent discrimination against the ill. This is the key message that missionaries such as Artur, a former alcoholic and private storeowner now in his thirties and working for KamUnion, try to communicate during their encounters with native Kamchatkans:

Yes, we walked right through the village, we met with people, stopped them, talked to them, gave them literature, invited them to service, told them about Jesus, that's it. It was kind of interesting. Some people listened, some didn't [and replied] 'We worship spirits, we have our own god, we are pagans, goodbye!' And I'm like 'And so what? Do pagans not get sick?'- 'Yes we do. What do you want?' - 'Well, we have a doctor with us and He wants to heal you'- 'Really?' - 'Yes, just come to our Saturday service and He will look at you'. Just like that, and they came. Well, we didn't push anybody. If someone wants to come, please. Then we held a service there, we prayed, people repented. That's what happened. It was God's movement (dvizhenie Bozhe bylo). We had a great time. (Artur 2011)

To cure the sick and integrate them into KamUnion, the shock therapy applied in the 1990s and that consisted in labeling "nearly all indigenous traditions as shamanism" and prohibiting KamUnionists "from anything remotely smacking of shamanism, including 
dancing, singing, or even playing a Koryak skin drum" (King 2011:98-99) did not prove effective. Another approach was to develop a treatment capable of countering the pathology with a mixture partially derived from the shamanism from which patients suffer. The recipe did not follow the Korean model, where "one of the key reasons for ... pentecostalism's extraordinary growth is its unerring ability to absorb huge chunks of indigenous ... shamanism" (Cox 2001:222). According to Pastor Valodia, a former Lieutenant Captain in the Kamchatkan commercial marine now in his forties who was born again in the early 1990s, only small but powerful chunks have been absorbed by World-Jesus:

When these guys, Evens or Koryaks, play the drum and sing their native songs in their native rhythms, that's one thing, but when they start to compose the word of God in native rhythms, that is, when they worship God with the drum, you must understand, it's just a huge force, it's just... so much power is released! (Valodia 2011)

In Northern Kamchatka, 'holy drumming' not only brought native people closer to the word of God, it also helped them modulate the 'noise' of neo-Pentecostalism in their own terms. In 2006-07, when a real drum was not available in the Church of Jesus, a Yamaha keyboard brought by missionaries was often used to reproduce the beat and the sound of this instrument. This in turn made it easier to make use of the musicality of drumming as a "transposable message" (Csordas 2009: 5) on the Kamchatkan roads of the Full Gospel. While drumming is not as central in the "manner of conduct" (manera povedeniia) of urban congregations as it is in the North, it is now a valued ritual practice and a valid missionary tool all across KamUnion. These ritual bricolages on the go involving drums are not unique to the Russian Far East. Describing how Inuit Pentecostal movements "often encourage their adherents to travel abroad", Laugrand and Oosten show how "[d]uring these trips Christian and Inuit traditions are integrated, notwithstanding the shamanic connotations of the latter" (2007:245). The transnational movement allowing for the combination of shamanism and Christianity makes possible to present the Inuit drum as "the heartbeat of life"" and to "heal the land" in the Canadian Eastern Arctic (Ibid.: 245, 247). A similar process is observable at a transcultural (and transethnic) level in Kamchatka, where "Pentecostal 'travelling culture" (Wanner 2010: 207) transformed the drum into a medium for the spread of a "huge force" across the Peninsula. Drumming (and to a lesser extent dancing) became as vital within KamUnion as it already was in other environments, including nonreligious ones (see Koester 2002; King 2011).

\section{Sick of shamanizing: The roots of the disease}

The idea that large-scale mobility across KamUnion heals those who travel was almost fully confirmed when itinerant Brothers and Sisters from the North came back to villages like Berezova. For ex-alcoholics who returned home perfectly sober and exhooligans who made the trip back gentle as a lamb, the recovery was spectacular. But for Maria who was still playing the drum publicly when she reintegrated her old universe, a doubt was possible. Apparently, Maria had found a way to escape her deadly family legacy and was not sick from the inside anymore. Yet at the same time her enduring faith in the drum could be seen as a sign of standstill despite the obvious transformation of herself. What was clear with alcoholism and hooliganism - i.e. that mobility across 
World-Jesus works as remedy - was less evident with shamanizing. As a result, the line of rupture between the soon-to-become healthy Christians and the never-to-be-healed pagans was pushed beyond musical and choreographic performances. As of 2007, what remained highly contagious in the view of Maria and other church leaders were the sequences performed in interaction with the tree of luck during Ololo. Anna did not quit the Church of Jesus because she liked to play the drum and dance like elders who know how to imitate seals or seagulls in their dances. She quit because she could not stop 'messing' with wood during the yearly collective ritual.

Maria had a bad feeling about some species of wood that grow around Berezova. Alder in particular reminded her of all those who died in her family and who have been buried too early in the village cemetery. This feeling is reinforced and amplified every year when the time of Ololo comes. In 2006, the annual replay of the ritual was scheduled for Monday, October 30. Had she wanted to, Maria could not ignore what was going on around her that day. She knew because the trail that leads to Ololo is routinized and constitutes a shared knowledge in Berezova. Every fall the same scenario is replayed. For days people fret that a lack of fresh meat threatens the organization of the ritual. Towards the end of October or early November, a seal is suddenly brought back from the seashore. Early the next day, a male elder dresses in his best suit, grabs an axe, walks towards the edge of the cemetery, and cuts two or three young alder trees in the vicinity of Orthodox burials. Before dawn, the trees are brought to the house of one of the families who take turn in the organization of Ololo. From dawn to dusk, women prepare the supper that will be offered to and shared with the villagers. After dinner, the trees are introduced into the ritual space (and become the tree of luck). Their warm welcoming generates some of the most animated moments of the whole celebration. For hours, the celebration goes on and on in a riot of drumming, dancing, and singing. These kinds of practices represent a paroxysm of idol worshipping within KamUnion.

In other parts of World-Jesus, especially in "the city" (gorod) that looks so remote from Berezova, only the Holy Spirit "is powerful enough to bend trees". Natural elements are useless "without being mentored [by the Spirit]" (bez nastavnichestvo). Things are different in Berezova, where the apparently simple acts performed by charismatic elders such as Spiridon who are in charge of cutting the trees require a special awareness - find the right trees at the right distance from the graves, pick up the right number of alder, look through their branches, and literally invite them home for twenty-four hours. More generally speaking, alder plays a central role in the fabrication of ancestors: bits and pieces of alder branches are thrown into the coffins of dead people before they are buried in the cemetery; stems are taken near the graves and work as entry ticket for commemoration meals; and the number of trees cut for Ololo often approximates - voluntarily or not - the number of human deaths that occurred since the last performance of the ritual. At the same time, alder also maintains a special relationship with birth and is essential for the rejuvenation of prey animals. During Ololo, the branches of the tree of luck are torn off by hunters who use them to craft a new wooden skeleton for each seal/bear/sheep killed during a year of hunting. Once fixed into their new bodies, prey animals are entertained during an entire night of festivity. Just before dawn the next day, the special animal guests (as well as what is left 

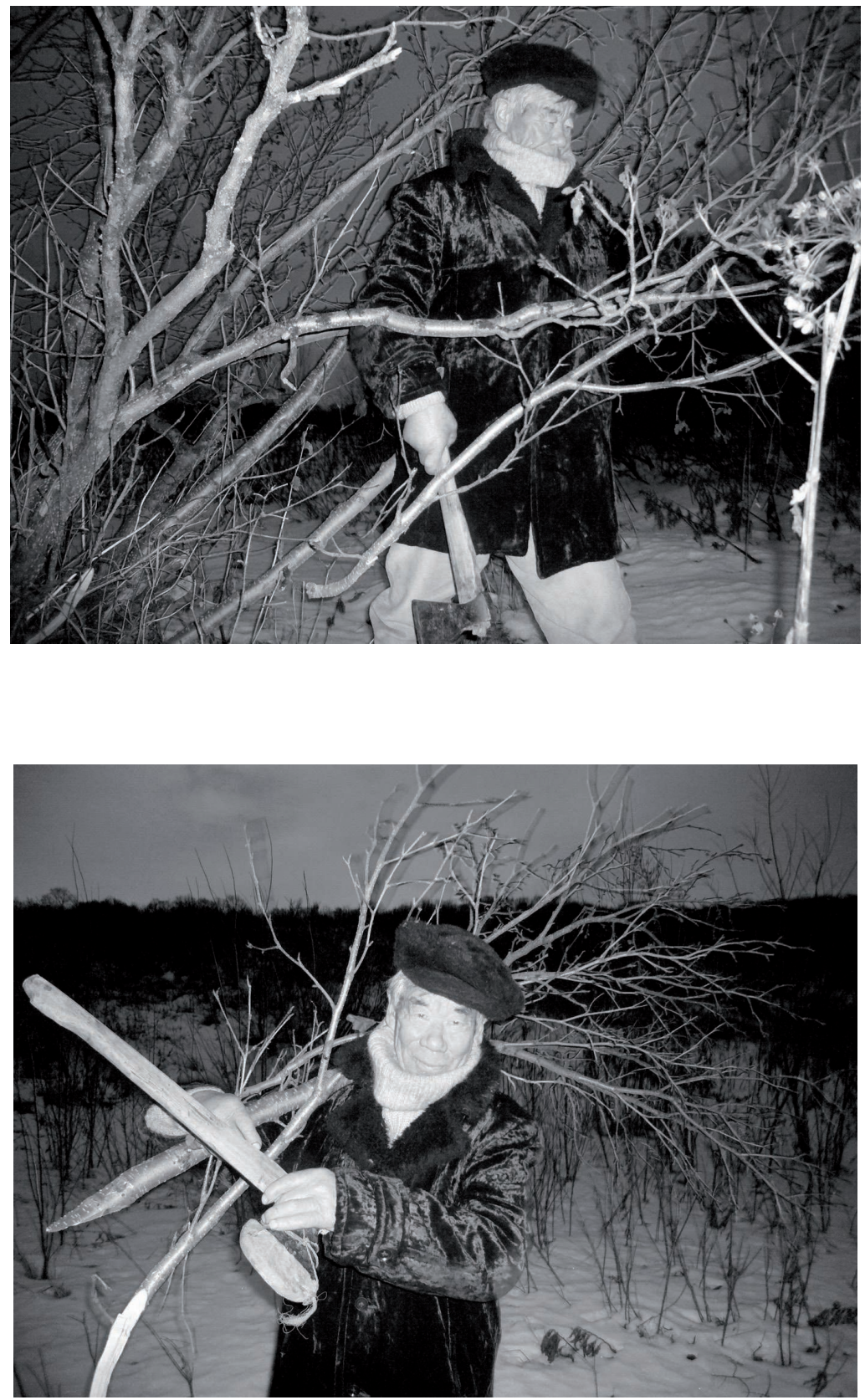

Photos 6 and 7: Spiridon, dressed in his nicest Persian lamb coat and hat, looking for alder trees and taking them to Ololo.

(C) Patrick Plattet, October 30, 2006. 
from the tree) are accompanied back in the vicinity of the cemetery from where they are now ready to "go back home" (Plattet 2011). From an analytical perspective, all this looks like an enactment, on a miniature scale and in a compressed-time format, of the pattern of "dying and being born again" (Laugrand 2002) that Maria went through during her life-changing journey across World-Jesus. The difference being that in her case, it is God and the ecclesiastical hierarchy who asked her to complete a full cycle of reincarnation, and who presided over her transformation. On the other hand, ancestors and wooden animals were seen by her as (mis)guided and colliding by the fault of idolatrous hunters who have always depended too much on them.

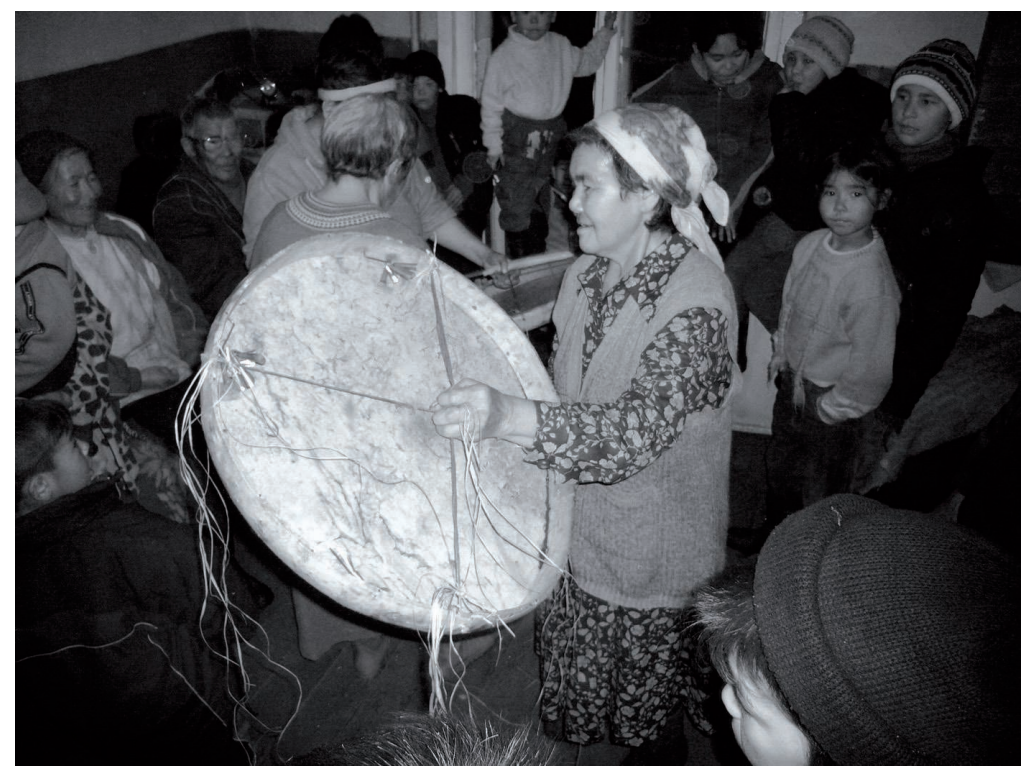

Photo 8: Woman elder drumming during the 2006 edition of Ololo in Berezova. (C) Patrick Plattet.

Other events that occurred in 2006 were seen by Maria as evidence that Ololo was a wrong, unhealthy, and therefore shamanic ritual. The last-minute change of venue of the ritual from Spiridon's apartment to Anna's place was one of them. The sons of Spiridon had started the party too early and were anticipating the welcoming of the tree with shots of vodka. While drinking is fine during Ololo (a home-brewed beer called braga is prepared for the occasion), too much vodka may spoil the festive reception of the guests. Such problems were not surprising to traveling members of the Church of Jesus. At the northern margins of World-Jesus, idolatry goes along with alcoholism, and rituals like Ololo are a fertile ground for the mutual production of deadly diseases. That being said, Anna did not drink and was not sick. She needed dental care and used to joke about her "scary" smile, but she was not dying. She was tired. Tired of not seeing her husband. Tired of not knowing how to deal with her former Brothers and Sisters. Tired of not knowing whether or not Ololo was a good thing for her and her family. Should she go back to the church? Should she keep getting close to the tree (and enjoy it)? In 2006, others made the decision for her. The move to Anna's place was decided by Spiridon's wife, a "grandmother" (babushka) and a member of the church. 
Together with other Sisters, Anna prayed to God for a "nice Ololo without too many drunk people". More intimately, she also asked God to help her husband encounter enough luck on his hunting trails, and assist her 18-year old son in joining the army, so that he could find a way out of the North and get married as far as possible from the land of his ancestors.

\section{Conclusion}

Elders in Berezova do not have an explanation of why alder is better than birch, or why the edge of the cemetery is a good place to find young alder trees. In their exegeses, leaders of the Church of Jesus do. They argue that individuals like Spiridon do that mechanically and by (blind) solidarity with others who did exactly the same before them. This view reflects an idea that is widely spread in Berezova. While it is critical to replay Ololo every fall, there is no consensus on why this is important and on how the ritual should be done. To some extent, the principle of deference (Bloch 2004) guides the ritual actions performed every fall in Berezova: "We're doing Ololo because our ancestors [who knew] did it before us". Within KamUnion, it is precisely the recognition that nothing validates Ololo except the necessity to copy the past that makes it "boring", and that constitutes evidence of its shamanic power. If participants do not have a shared understanding of what to do during the ritual, and yet are still able to perform it collectively, then the ritual has a life of its own. Somehow, it acts upon those who act upon idols. Even though a majority of participants consider Ololo to be a revitalizing event, and experience it very differently from year to year, the 'uncertain certainty" of its annual replay opens a gap through which "dirt" is disseminated across ages. Since the $18^{\text {th }}$ century, Christian missionaries of all sides who were sent to Berezova have seen alder as the substance by means of which deadly idols and diseases are fabricated and perpetuated. For them, the long-term unexplained trust in this substance means that something is being carried through those who attach too much importance to it. Even in 2006, something in Anna 'belonged' to others before her. She was not entirely new because she never found her way out of the archaic past and was not able to produce enough discontinuity in her life. Even though Anna was not medically sick with idolatry, she was clearly sick of shamanizing. And she ignored it. For Anna, however, drumming, dancing, and crafting wooden animals was anything but boring. After each Ololo she felt really good for a while. Her tiredness seemed to emerge, rather, from the tension between the deferential pressures to tradition on the one hand, and the social pressures of the new "healthier" Good News ideas and practices on the other.

Anna's situation is not unique. Many rural congregations of KamUnion who experienced a rapid growth in the turmoil of the 1990s were facing decrease in membership a decade later. Even in Berezova, an exemplary "stronghold of stability" according to many pastors-missionaries, members of the Church of Jesus were nostalgic about the enthusiasm of the early years. Politically and socially, the congregation had found its place in the community, in part as a result of its social campaigning against (and religious treatment of) alcoholism. But at the same time, for people like Anna who have never been alcoholic and who were trying to understand the difference between shamanizing and idol worshipping, attending the church was not the solution. Traveling 
far would not have helped either, as the distinction among idolatrous pagans, shamans, and worshippers is even more blurred within the broader realm of World-Jesus.

In Apala, members of the Church of the Testament of Life were increasingly concerned about their religious marginalization in 2011. The first priority was to "not disrupt" and work together with the political and religious authorities. Maria was still the only woman serving as full-time pastor within KamUnion. She was not, however, the only woman with charismatic responsibilities. In Berezova and elsewhere, many (native) women are encouraged to step in when a pastor is told by God to go on a mission somewhere else. For them, the prospect of being enabled to travel was getting closer, and with it, the opportunity to discover how rejuvenating the Koryak drum can be on the Kamchatkan roads of World-Jesus.

\section{References}

BeEr, Daniel, 2004. "The Medicalization of Religious Deviance in the Russian Orthodox Church (18801905)", Kritika: Explorations in Russian and Eurasian History, 5(3): 451-482.

Belashov, A. I., 2000. "Kamchatskaia Eparkhiia (Stranitsy Istorii)", in P. P. Gromov, Istoriko-statisticheskoe opisanie kamchatskikh tserkvei, 232-262. Petropavlovsk-Kamchatskii: Skrizhali Kamchatki.

Bцосн, Maurice, 2004. "Ritual and Deference", in Harvey Whitehouse and James Laidlaw (eds), Ritual and Memory, 65-78. New York, Oxford: AltaMira Press.

Cohen, Ariel, 2006. "Putin's Legacy and United Russia’s New Ideology”, Backgrounder, 1940: 1-12.

Cox, Harvey, 2001 [1995]. Fire from Heaven. The Rise of Pentecostal Spirituality and the Reshaping of Religion in the Twenty-First Century. Cambridge, Mass.: Da Capo Press.

Csordas, Thomas, 2009. " Modalities of transnational transcendence. Introduction », in Thomas Csordas (ed.), Transnational Transcendence. Essays on Religion and Globalization, 1-29. Berkeley: University of California Press.

De Lesseps, Jean-Baptiste B., 1970 [1790]. Travels in Kamtschatka, During the Years 1787 and 1788. New York: Arno Press and the New York Times.

Dombrowski, Kirk, 2001. Against Culture: Development, Politics, and Religion in Indian Alaska. Lincoln: University of Nebraska Press.

Donahoe, Brian and Joachim O. HAвеск (eds), 2011. Reconstructing the House of Culture. Community, Self, and the Makings of Culture in Russia and Beyond. New York, Oxford: Berghahn.

Droogers, André, Kim Knibie and Regien Smit, 2010. "Guest Editorial: Mobility, Time and Space in Pentecostalism", PentecoStudies 9(2): 145-152.

Gooren, Henri, 2010. "Conversion Narratives", in Allan Anderson, Michael Bergunder, André Droogers, and Cornelis Van Der Laan (eds), Studying Global Pentecostalism. Theories and Methods, 93-112. Berkeley: University of California Press.

Gromov, P.P., 2000 [1857]. Istoriko-statisticheskoe opisanie Kamchatskikh tserkvei. PetropavlovskKamchatskii: Skrizhali Kamchatki.

Hamayon, Roberte N., 1998. “'Ecstasy' or the West-Dream Siberian Shaman”, in Helmut Wautischer (ed.), Tribal Epistemologies. Essays in the Philosophy of Anthropology, 175-187. Aldershot, Brookfield: Ashgate.

Invictory, Christian Megaportal, 2010. "The President of the Missionary Centre 'World-Jesus' answered questions", online: http://www.invictory.org

Jochelson, Waldemar, 1908. The Koryak. Memoirs of the American Museum of Natural History vol. VI, parts 1-2: The Jesup North Pacific Expedition. Leiden: E.J. Brill; New York: G. E. Stechert. 
KING, Alexander D., 2003. "Social Security in Kamchatka. Rural and Urban Comparisons", in Chris Hann and the "Property Relations" Group (eds), The Postsocialist Agrarian Question: Property Relations and the Rural Condition, 391-418. Münster: Lit Verlag.

-, 2011. Living with Koryak Traditions. Playing with Culture in Siberia. Lincoln: University of Nebraska Press.

Koester, David, 2002. "When the Fat Raven Sings: Mimesis and Environmental Alterity in Kamchatka's Environmentalist Age", in Erich Kasten (ed.), People and the Land: Pathways to Reform in PostSoviet Siberia, 45-62. Berlin: Dietrich Reimer Verlag.

Koester, David, Victoria V. Petrasheva and Tatiana S. Degai (eds), 2010. Church, Faith and Contemporary Life: Remembrances and Stories from Tigil. Petropavlovsk: Novaia Kniga.

LAMBERT, Jean-Luc, 1999-2000. "La fête nénetse de l'éleveur de rennes", Études mongoles et sibériennes, 30-31: 47-72.

LAUGRAND, Frédéric, 2002. Mourir et renaître: la réception du christianisme par les Inuit de l'Arctique de l'Est canadien. Québec: Les Presses de l'Université Laval.

Laugrand, Frédéric and Jarich Oosten, 2007. "Reconnecting People and Healing the Land: Inuit Pentecostal and Evangelical Movements in the Canadian Eastern Arctic", Numen, 54: 229-269.

Luehrmann, Sonja, 2005. "Recycling Cultural Construction: Desecularisation in Postsoviet Mari El", Religion, State \& Society, 33(1): 35-56.

Lunkin, Roman, 2004. "Traditional Pentecostals in Russia", East-West Church \& Ministry Report, 12(3): 4-7.

-, 2005, "The Charismatic Movement in Russia", East-West Church \& Ministry Report, 13(1): 1-3.

Meyer, Birgit, 1998. "“Make a Complete Break with the Past': Memory and Post-Colonial Modernity in Ghanaian Pentecostalist Discourse”, Journal of Religion in Africa, 28(3): 316-349.

Panchenko, Alexander, forthcoming. “Triasuny’: Distsiplinarnoe Obshchestvo, Politicheskaia Politsiia i Sud'by Piatidesiatnichestva v Rossii", Antropologicheskii Forum.

Plattet, Patrick, 2011. "Landscapes in motion: Opening pathways in Kamchatkan hunting and herding rituals", in Peter Jordan (ed.), Landscape and Culture in Northern Eurasia. Walnut Creek: Left Coast Press.

RobBins, Joel, 2010. "Anthropology of Religion“, in Allan Anderson, Michael Bergunder, André Droogers, and Cornelis Van Der Laan (eds), Studying Global Pentecostalism. Theories and Methods, 156-178. Berkeley: University of California Press.

Robert-Lamblin, Joëlle, 2011. "Ethno-histoire récente et situation contemporaine des Évènes de la région Bystrinskij (Kamtchatka central, Extrême-Orient russe, 2004)", Revue d'études comparatives EstOuest, 42(4): 107-147.

Steller, Georg W., 2003 [1774]. History of Kamchatka: Collected Information Concerning the History of Kamchatka, Its Peoples, Their Manners, Names, Lifestyles, and Various Customary Practices. Fairbanks: University of Alaska Press.

UrKachan, Aleksandra, 2002. 'Vèemlen', zemlia moikh predkov. Petropavlovsk-Kamtchatski: Kamchat.

Vallikivi, Laur, 2003. "Minority and Mission: Christianisation of the European Nenets", Pro Ethnologia, 15: $109-130$.

-, 2009. "Christianization of Words and Selves: Nenets Reindeer Herders Joining the State through Conversion", in Mathijs Pelkmans (ed.), Christian Conversion after Socialism: Disruptions, Modernisms and the Technologies of Faith in the Former Soviet Union, 59-83. Oxford: Berghahn.

Vaté, Virginie, 2009. "Redefining Chukchi Practices in Contexts of Conversion to Pentecostalism", in Mathijs Pelkmans (ed.), Christian Conversion after Socialism: Disruptions, Modernisms and the Technologies of Faith in the Former Soviet Union, 39-57. Oxford: Berghahn.

VDovin, I. S., 1973. Ocherki etnicheskoi istorii Koriakov. Leningrad: Nauka. 
Wanner, Catherine, 2010. "Up and Out: Movement and Mobility among Pentecostals in Eurasia", PentecoStudies, 9(2): 195-210.

ZnAmenski, Andrei, 1999. Shamanism and Christianity: Native Encounters with Russian Orthodox Missions in Siberia and Alaska, 1820-1917. Westport: Greenwood Press.

\section{Interviewees:}

AleXANDER (pseudonym), interview made on June 8, 2011 at his home; transcript in author's possession. ARTUR (pseudonym), interview made on June 22, 2011 at the church; transcript in author's possession. Boris (pseudonym), interview made on June 24, 2011 at the church; transcript in author's possession.

VALODIA (pseudonym), interview made on June 20, 2011 at his home; transcript in author's possession. 